\title{
SIZE AT SEXUAL MATURITY OF NIPA-OBLIGATE CRAB Labuanium politum (CRUSTACEA: SESARMIDAE); HARVESTING PLAN PRECEDING COMMERCIALISATION
}

\author{
SITI AKMAR KHADIJAH AB RAHIM, AKMA IDDIN MASINI* AND NUR AMIRAH \\ MOHAMAD ALWIE
}

Faculty of Resource Science and Technology, Universiti Malaysia Sarawak, 94300 Kota Samarahan, Sarawak, Malaysia.

*Corresponding author: akmamasini@gmail.com

Submitted final draft: 28 November 2019 Accepted: 15 December $2019 \quad$ http://doi.org/10.46754/jssm.2020.07.003

\begin{abstract}
Labuanium politum (De Man, 1887) is in demand for consumption in certain parts of Sarawak, Malaysia. It is still in the initial stage of commercialisation as one of the local food sources and for subsistence income. In the interim, questions have been raised on how to reconcile the needs between resource utilisation and conservation. Herein, this study aimed to estimate the size at sexual maturity of L. politum and suggesting possible sustainable harvesting guideline to conserve the natural stocks. A total of 288 individuals comprised 149 males and 139 females, of which 12 were berried, that were examined for the stages of gonad. Size at sexual maturity, $\mathrm{SM}_{50}$ is at $14 \mathrm{~mm}$ of carapace width for males and $19 \mathrm{~mm}$ for females. The size at sexual maturity estimations fitted with the morphological observations of gonad stage in the current study. Highest frequency of individuals with fully developed gonad were observed in July and August and this suggests the harvesting seasons should be ideal in the preceding months to allow higher success rate in mating. The present study aimed to develop strategies that will ensure a sustainable harvest for this species in Sarawak, Malaysia.
\end{abstract}

Keywords: Sesarmid, gonadal maturation, resource management.

\section{Introduction}

Determining the size of the sexual maturity of fish and crabs has been the focused research topic, principally important for the management of fishery resources (Leme, 2005). Size at sexual maturity is the most important parameters in studying the life history of an organism (Abrams $\&$ Rowe, 1996). The gonads of crabs are in the cephalothorax above hepatopancreas (Silva et al., 2012). The male reproductive system consists of a pair of testes, a pair of vas deferens and two pairs of gonopods (Erkan et al., 2009) and the female reproductive system consists of a pair of ovaries, ovarian ducts and a pair of spermathecae (Silva et al., 2012). Histological methods are commonly used to determine the development of gonads and maturation (Silva et al., 2012). Besides that, the gonadal development stages can also be recognised from the outer morphological appearances as had been done on Sesarma rectum (Leme, 2005), Anamathia rissoana (Mura et al., 2005), and
Armases rubripes (Lima et al., 2006). Size at sexual maturity studies usually steered on several commercially exploited crab species such as Eriphia verrucosa (Erkan et al., 2009), Portunus pelagicus (Ikhwanuddin et al., 2009), Scylla paramamosain (Islam \& Kurokura, 2013), Goniopsis cruentata (Hirose et al.,2015) and Callinectes danae (Marochi et al., 2013).

Labuanium politum is an obligate arboreal crab that inhabits the nipa palm tree. The present study found that the local market for L. politum can fetch between RM40.00 and RM50.00 (USD 9.54-11.93) per kg. The species could potentially support the indigenous food and ecotourism industry in Sarawak. In line with that, commercialisation is expected to take place very soon. Besides that, $L$. politum has also been reported in Labuan (Malaysian Borneo), Ubin Island (Singapore) and Loboc River (Philippines) by $\mathrm{Ng}$ et al., (2015) which only covered taxonomic and ecological aspects. We have observed the impacts of human activities 

at nipa forests including exploitation of this crab for food by certain areas in the western part of Sarawak and the findings will be published. A recent study had found that $L$. politum in a small area of nipa forest had disappeared after being exploited uncontrollably which might have been due to overexploitation. The carrying capacity of this unique crab species towards human exploitation has come into showdown which will undoubtedly be disapproving to both parties soon. The authors believed the dispute can be resolved by suggesting suitable harvesting guidelines to sustain the wild stocks of L. politum.

Therefore, this research set out to estimate the size at sexual maturity of $L$. politum from selected nipa forest in Malaysian Borneo within certain periods of the study. The findings were obtained by interpolation percentage of matured individuals based on the carapace width size classes. Once the size at half population to be matured $\mathrm{SM}_{50}$ were known, ideal harvesting size limit and seasons can be suggested. In the end, the information in this research would provide better harvesting guideline for L. politum in the future. This solution employed to ensure the survival of this Sesarmid climbing crab in the complex environment of nipa forests must not be lost.

\section{Materials and Methods}

\section{Samples Collection}

Crab samplings were carried in six months (June, July, August, November, December 2017 and January 2018) with a two-month break between August and November in Tambak, Sarawak (N 1³7'15.19”; E 111¹7’6.71”) (Figure 1).

The crabs were collected using spear-hook locally known as 'pengait'. Immediately, the crabs were sedated in ice and measured for the carapace width $(\mathrm{CW}) \mathrm{mm}$. Approximately 45 individuals were collected monthly from each sampling representing $400 \mathrm{~m}^{2}$ of the plot sizes. Throughout the study, a total of 288 individuals was collected which comprised 149 males, 139 females of which 12 were berried.

\section{Stages of Gonadal Development}

The identification of the gonad was adopted from the morphological gonadal characteristics of other mangrove crab species reported by Lima et al., (2006) and Marochi et al., (2013). The stages of gonad for male and female crabs were

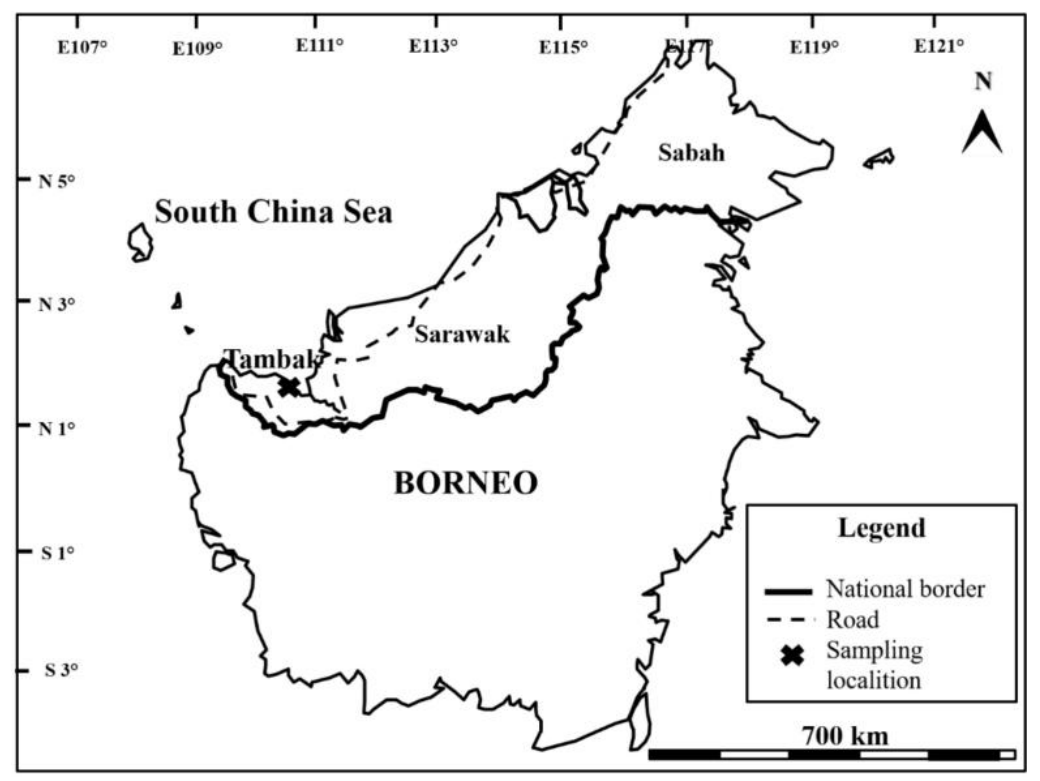

Figure 1: Sampling location for L. politum study at southwestern part of Sarawak, Malaysia 
categorised into four groups (Table 1) which are based on colour, shape and size (Figures 2 and
3). These observations were made using stereo microscope (Brand; OLYMPUS, Model; SZ51).

Table 1: Labuanium politum: Descriptions on the stages of gonadal development for males and females

\begin{tabular}{ll}
\hline \multicolumn{1}{c}{ Stages of Gonadal Development } & \multicolumn{1}{c}{ Description } \\
\hline $\begin{array}{l}\text { Immature (IM) } \\
\text { Intermediary A (INT A) }\end{array}$ & Male \\
Intermediary B (INT B) & Vas deferens can be observed (Whitish) \\
Fully developed (DE) & Vas deferens is translucent with a little entwined (Whitish) \\
Immature (IM) & Fully developed gonads with vas deferens (Pale yellow) \\
Intermediary A (INT A) & Gonads undifferentiated \\
Intermediary B (INT B) & Ovary can be observed in filamentous (Yellowish) \\
Fully developed (DE) & $\begin{array}{l}\text { Ovary with lobes and the ratio of ovary with hepatopancreas } \\
\text { approximately 1:2 (Bright orange) }\end{array}$ \\
\hline
\end{tabular}
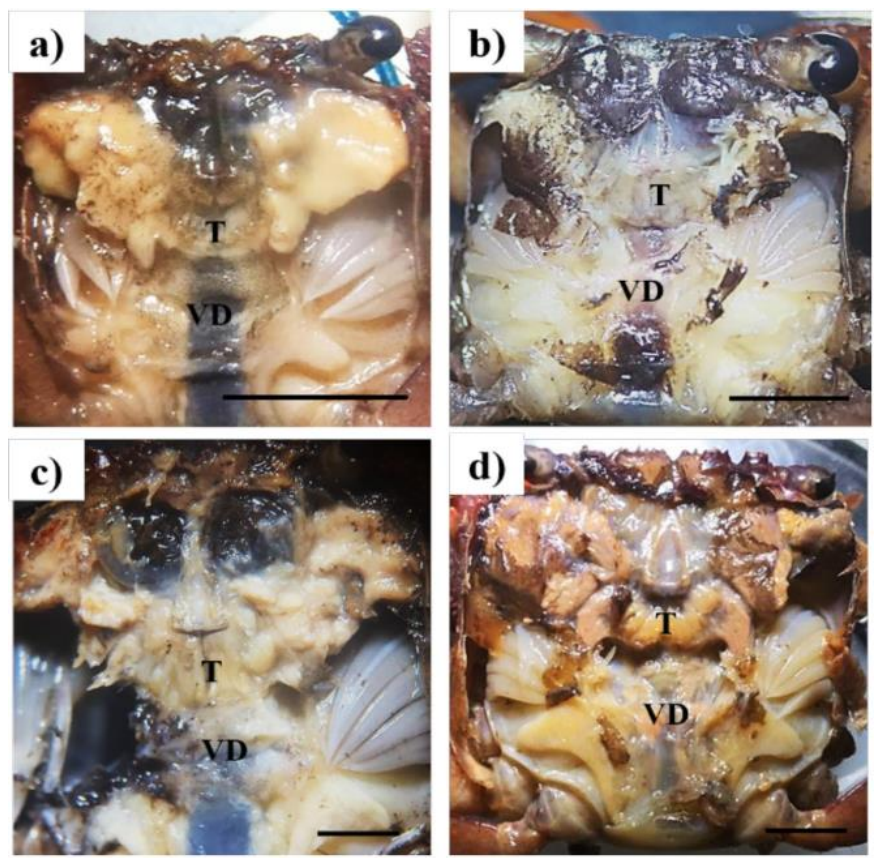

Figure 2: Dorsal view of L. politum (male) with different colours and size of reproductive organs. a) IM stage,

B) INT A stage, c) INT B stage, d) DE stage with $T=$ testes, VD = vas deferens and scale bar $=1.00 \mathrm{~mm}$ 

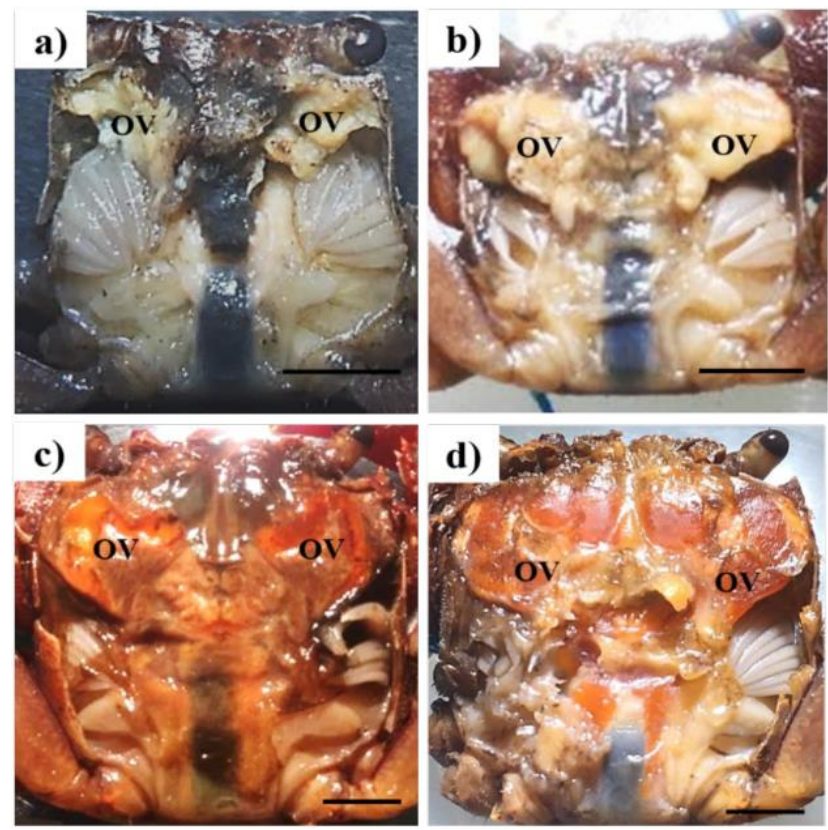

Figure 3: Dorsal view of $L$. politum (female) with different colours and size of reproductive organs. a) IM stage, B) INT A stage, c) INT B stage, d) DE stage with OV $=$ ovaries, and scale bar $=1.00 \mathrm{~mm}$

Logistic Growth Graph for Estimation of $S_{50}$ Analogous with other crab studies by Leme (2005) and Öndes et al., (2017), L. politum classified at INT A and INT B stages of gonad was considered as mature, DE as fully mature while, the IM stage was classified as juvenile or immature. The percentage of mature samples (\%) for both sexes, including samples from INT A until DE stages were plotted against each 5mm size classes (5-9 mm, 10-14 mm, 15-19 $\mathrm{mm}, 20-24 \mathrm{~mm}, 25-29 \mathrm{~mm}$ and $30-34 \mathrm{~mm}$ ) to obtain logistic growth graph. Then, in the transition phase between size classes with $0 \%$ and $100 \%$ maturity, only the individuals with fully developed gonads were plotted to fit the logistic growth graph and attained size at 50\% of mature population, $\mathrm{SM}_{50}$.

\section{Statistical Analyses}

CW sizes were Log transformed to achieve normality of the data. All the statistical analyses were tested at 95\% confidence limit (Zar, 1996). Sekiguchi et al., 1998 suggested on Tachypleus gigas that juvenile females might undergo one stage up in moulting compared to males. Thus, the following null hypothesis constructed: $\mathrm{H}_{0}$ $=$ Juvenile $L$. politum females and males are of equal size. Since the samples categorised in IM stages were low $(n=6)$, non-parametric Mann Whitney $U$ test was used to test differences between sizes of both sexes.

In crustaceans, the size between males and females might be different after reaching maturity. This might due to the sexual dimorphism, competition for mate and territory (Christy, 1987; Saher \& Qureshi, 2012; Dvoretsky \& Dvoretsky, 2014). Whilst, another null hypothesis had been raised concerning the size of males and females L. politum after reaching maturity; $\mathrm{H}_{0}=$ Size between males and females $L$. politum after passing juvenile stage are equal. In order to prove the hypothesis, only samples classified between INT A, B and DE stages were compared with Two-Way ANOVA and followed by multiple comparisons, Bonferroni test to verify the differences. 


\section{Results}

Carapace width, $\mathrm{CW}$ of individuals ranged from 8.32-33.64 $\mathrm{mm}$ for males (mean \pm standard deviation; $23.05 \pm 5.82 \mathrm{~mm}$ ) and 11.42-32.74 $\mathrm{mm}$ for females (mean \pm standard deviation; $22.23 \pm 4.92)$. The berried female $\mathrm{CW}$ ranged from 19.80-29.06 (mean \pm standard deviation; $24.05 \pm 2.84$ ). Table 2 displays the size data for each sex in different gonadal development stages.

Table 2: Variation in size for each sex of L. politum at different gonadal stages

\begin{tabular}{ccc}
\hline $\begin{array}{c}\text { Stages of } \\
\text { Gonadal } \\
\text { Development }\end{array}$ & \multicolumn{2}{c}{ Carapace width ranged (mm) } \\
\cline { 2 - 3 } & Male & Female \\
\hline IM & $8.32-13.36$ & $12.64-16.50$ \\
INT A & $11.86-20.82$ & $11.42-20.44$ \\
INT B & $12.42-27.90$ & $15.12-30.36$ \\
DE & $17.54-33.64$ & $19.80-32.74$ \\
\hline
\end{tabular}

\section{Comparisons of CW Sizes between Sexes for All Stages of Gonad}

Based on size between sexes of different gonadal stages (Figure 4), the sizes for IM stage were showing no significant difference between males and females; Mann Whitney, $\mathrm{U}=0.136$, $p=0.4875$. Meanwhile, in stages of INT B - DE, males and females showed significant difference in size; Two-way ANOVA, $\mathrm{F}=16.25$, $\mathrm{df}=2$, $p=0.000$. Then, multiple comparison analyses showed that females were statistically bigger at INT B stage while, males were statistically bigger at DE stage; Bonferroni, $p<0.05$. Besides, the size between males and females was not significantly different at INT A stage; Bonferroni, $p>0.05$.

\section{$S M_{50}$ and Temporal Variation}

Estimated size at half of the mature population $\mathrm{SM}_{50}$ in Tambak was signified at $14 \mathrm{~mm}$ for males and $19 \mathrm{~mm}$ for females (Figure 5). In addition, total maturation for the population was signified at 20-24 mm CW size class. Furthermore, this study also indicated that all stages of gonads were present in all sampling trips except for IM stage for the November trip (Figure 6). A total of 6 individuals categorised with IM stage were found in each trip ( $<5 \%$ of samples collected). The highest individuals of L. politum with fully developed gonads were recorded from the July and August trip (>50\% of samples collected). On the other hand, the lowest individuals with fully developed gonads were collected in NovemberJanuary (31\% of samples collected).

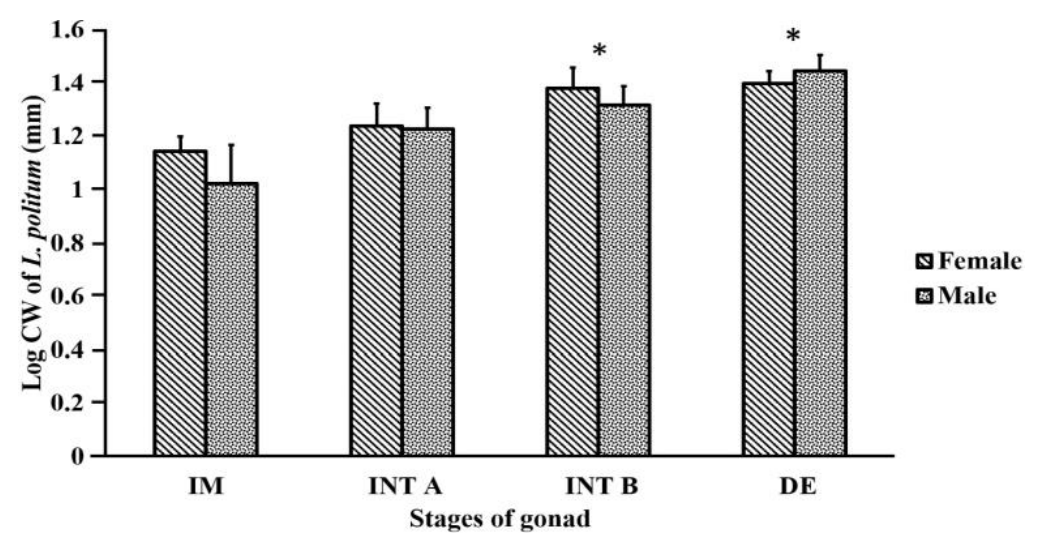

Figure 4: Comparison of size between all the gonadal stages for both sexes. * indicated significant differences between males and females for each gonadal stage (Bonferroni, $p<0.05$ ) 


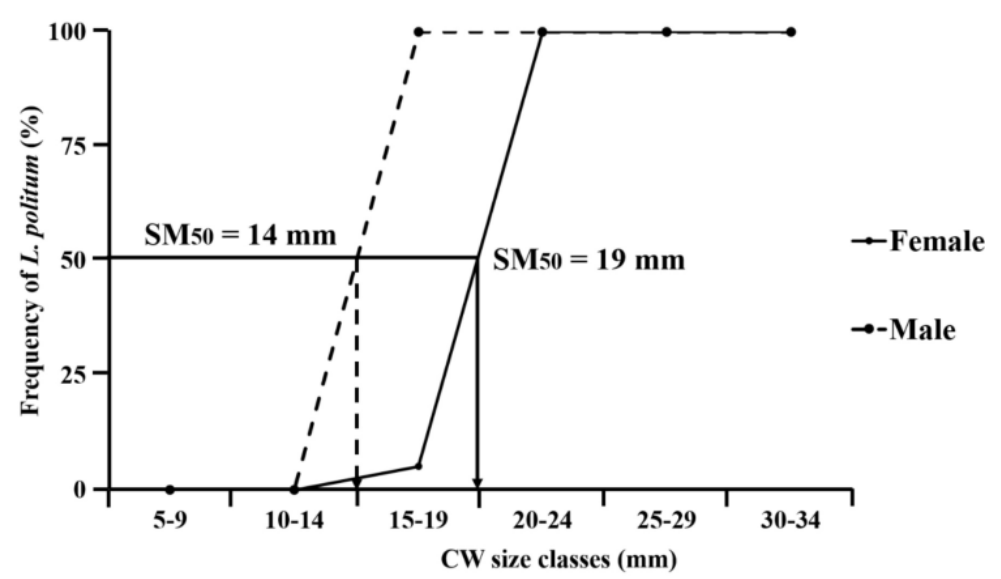

Figure 5: Logistic growth of L. politum from Tambak, Sarawak showing the $\mathrm{SM}_{50}$ for both male $(14 \mathrm{~mm})$ and female $(19 \mathrm{~mm}) \mathrm{X}$

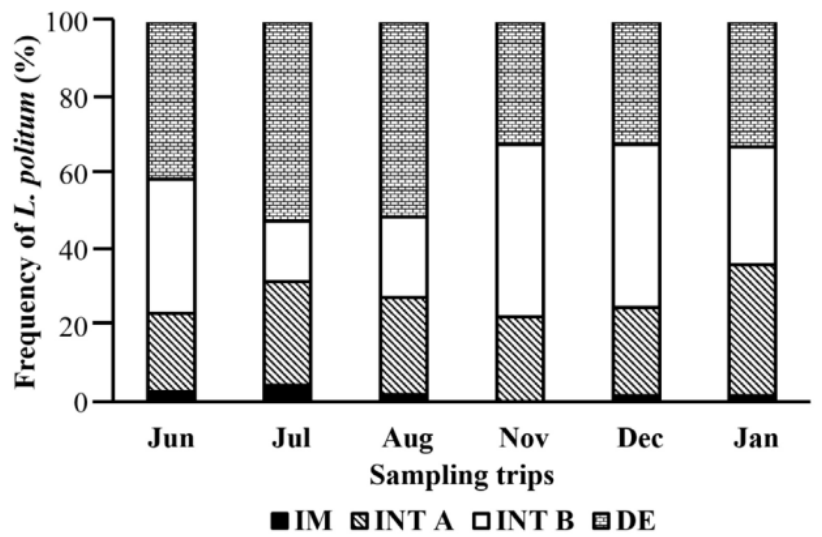

Figure 6: Temporal variation of L. politum in Tambak populations throughout all the sampling trips

\section{Discussion}

Growth of L. politum as it advances into different gonadal stages has never been reported yet. In terms of $\mathrm{CW}$ sizes, both male and female $L$. politum were evenly sized at earlier stages of gonadal development (IM and INT A). Dvoretsky and Dvoretsky, (2014) on red king crab Paralithodes camtschaticus suggested that at the earlier stages, sizes were the same between both males and females until reproductive age but in a recent study both male and female $L$. politum were showing significant differences in size after reaching INT B and DE stages. This study showed females were to be bigger than males after reaching INT B stage and this might due to the extension from gonadal development and external surface for carrying eggs on the abdominal pleopods which means larger berried female crabs with greater volume of eggs as being observed in Liocarcinus depurator (Rufino et al., 2004). But, L. politum males grow bigger than females at DE stage which might be related to different energy usage on their physical growth and reproductive biology (Charnov et al., 2001). Commonly in crabs that males exhibit a bigger size due to the territorial and mating selection behaviour while, female growth was more focusing on the development of reproductive organs (Saher \& Qureshi, 2012; Lavajoo et al., 2013). Although sexual size dimorphism which resulting in shape dimorphism has been observed in several 
crab species (Berns, 2013), this is absent in $L$. politum carapace in the present study.

During the maturation process, the morphological alterations in terms of volume and colour are easily seen by macroscopic inspection. The sequences in colour change was similar as reported for other freshwater crabs and the transparent ovaries developed to a whitish colour to cream, followed by yellow and end up with bright orange which shows from the accumulation of yolk (Rostant et al., 2008; Silva et al., 2012).

The $\mathrm{SM}_{50}$ were fitted for the present study as no berried females and individuals with fully developed gonads for both sexes were found with size less than the $\mathrm{SM}_{50}$ obtained. In this study, males L. politum achieved $\mathrm{SM}_{50}$ earlier than females which had been observed in Anamathia rissoana (Mura et al., 2005), Armases rubripes (Lima et al., 2006), Portunus pelagicus (Ikhwanuddin et al., 2009) and Cancer pagurus (Öndes et al., 2017). Unlikely, other crab species such as Eudaniela garmani (Rostant et al., 2008), Sylviocarcinus pictus (Silva et al., 2012), Callinectes danae (Marochi et al., 2013) and Goniopsis cruentata (Hirose et al., 2015) were reported vice versa. Maturation stages may vary depending on the species and the method used (Silva et al., 2012). For instance, for Armases rubripes, the females attain sexual maturity after the males and this might be due to the extension of abdominal development to allow greater support and ensure the moisture of the eggs during incubation (Lima et al., 2006). This reason could possibly explain the recent findings of $L$. politum $\mathrm{SM}_{50}$ between males and females. Other factors that can influence the $\mathrm{SM}_{50}$ value of crabs are the food consumed and food availability. Sufficient food intake by the males would probably promote earlier maturity compared to females as nutrients had been reported to contribute in crustacean maturity (Islam \& Yahya, 2017).

The temporal variation of gonadal development stages showed high availability of mature crabs throughout the six-month period. This indicates that $L$. politum may breed all year round but there is still a need to confirm this theory by monitoring its gonadal development stages pattern for one year. In contrast, immature crabs which are very small comprised less than $5 \%$ of monthly total samples probably due to its ability to hide deeper within narrow space of the nipa stalks. In addition, number of fully mature crabs peaked in the month of July and August but decreased in November to January. Variation in proportion of mature crabs within a population may give some hints on its breeding season. Reduction in fully mature L. politum compared to previous month showed that the main breeding period has already occurred. In Sarawak, June to August receive less precipitation than November to January. It seems that the copulation process may happen in drier months and crab larvae are release by females in wet months which will enhance the larval dispersal.

Therefore, it is suggested for now that collection period would be ideal after August. Based on the $\mathrm{SM}_{50}$, it is suggested that the ideal harvest size limit for $L$. politum should belarger than $24 \mathrm{~mm}$ because both sexes are predicted to achieve total maturation within $20-24 \mathrm{~mm}$ CW size class.. Besides, collecting should be performed at night. With current collecting gear, catching this nocturnal crab when it comes out from their hiding places would provide better chances to collect only matured individuals and protecting the smaller, juvenile and berried ones to ensure that the new recruitments become adults.

\section{Conclusion}

Present study had partially provided basic knowledge on the reproductive biology of $L$. politum in its natural habitat, namely the size at sexual maturity and temporal variation of gonadal development stages. These scientific findings are very crucial in making suggestions to the harvesting guidelines of this crab species in Sarawak since it has the potential to be commercialised. Based on the total maturation of population, it is suggested that the ideal harvest size for L. politum should be larger than 
$24 \mathrm{~mm}$ and crab collection must be avoided in July and August when high percentage of the population are in fully mature stage. A complete one-year gonadal development data is still needed in order to make better suggestions on managing the L. politum population sustainably and to predict its breeding cycle within a year.

\section{Acknowledgements}

The authors would like to thank Faculty of Resource Science and Technology, Universiti Malaysia Sarawak for facilities and equipment used in this study. Special thanks go to the villagers for their helps during sampling trips and Baitulmal Sarawak for the postgraduate study financial aids. Our most gratitude also goes to Prof. Maria Helena de A. Leme of Universidade Paulista, Brazil for her valuable advice in the data analysis of this manuscript.

Abbreviations: L. politum = Labuanium politum, $\mathrm{SM}_{50}=$ Size at sexual maturity.

\section{References}

Abrams, P. A., \& Rowe, L. (1996). The effects of predation on the age and size of maturity of prey. Evolution, 50(3), 1052-1061.

Berns, C. M. (2013). The evolution of sexual dimorphism: understanding mechanisms of sexual shape differences. Sexual Dimorphism. Intech Open, Rijeka, Croatia.

Charnov, E. L., Turner T. F., \& Winemiller, K. O. (2001). Reproductive constraints and the evolution of life histories with indeterminate growth. Proceedings of the National Academy of Sciences of the United States of America, 98(16), 9460-9464.

Christy, J. H. (1987). Competitive mating, mate choice and mating associations of Brachyuran crab. Bulletin of Marine Science, 41(2), 177-191.

Dvoretsky, A. G., \& Dvoretsky, V. G. (2014). Size-at-age of juvenile red king crab Paralithodes camtschaticus (Tilesius, $1815)$ in the coastal Barents Sea. Cahiers de Biologie Marine, 55, 43-48.
Erkan, M., Tunali, Y., Balkis, H., \& Oliveria, E. (2009). Morphology of testis and vas deferens in the Xanthoid Crab, Eriphia verrucosa (Forskal, 1775) (Decapoda: Brachyura). Journal of Crustacean Biology, 29(4), 458-465.

Hirose, G. L., Souza, L. S., Silva, S. L. R., Alves, D. F. R., \& Negreiros-Fransozo, M. L. (2015). Population structure of the red mangrove crab, Goniopsis cruentata (Decapoda: Grapsidae) under different fishery impacts: Implications for resource management. Revista de Biología Tropical, 63(2), 443-457.

Ikhwanuddin, M., Shabdin, M. L., \& AbolMunafi, A. B. (2009). Size at maturity of blue swimming crab (Portunus pelagicus) found in Sarawak coastal water. Journal of Sustainability Science and Management, 4(1), 56-65.

Islam, M. S., \& Kurokura, H. (2013). Gonad development and size at maturity of the male mud crab Scylla paramamosain (Forsskål, 1755) in a tropical mangrove swamp. Journal of Fisheries, 1(1), 7-13.

Islam, M. L., \& Yahya, K. (2017). Variations in age and size at sexual maturity of female green mud crab (Scylla paramamosain) under different captive grow out conditions. International Journal of Fisheries and Aquatic Studies, 5(4), 451-457.

Lavajoo, F., Kamrani, E., Sajjadi, M., \& Askari, M. (2013). Relative growth of the fiddler crab, Uca sindensis (Crustacea: Ocypodidae) in a subtropical mangrove in Pohl Port, Iran. Iranian Journal of Fisheries Science, 12(2), 639-653.

Leme, M. H. (2005). Size at sexual maturity of female crabs Sesarma rectum Randall (Crustacea, Brachyura) and ontogenetic variations in the abdomen relative growth. Revista Brasiliera de Zoologia, 22(2), 433437.

Lima, G. V., Soares, M. R. S., \& Oshiro, L. M. Y. (2006). Reproductive biology of the 
sesarmid crab Armases rubripes (Decapoda, Brachyura) from an estuarine area of the Sahy River, Sepetiba Bay, Rio de Janeiro, Brazil. Iheringia Série Zoologia, 96(1), 47-52.

Marochi, M. Z., Moreto, T. F., Lacerda, M. B., Trevisan, A., \& Masunari, S. (2013). Sexual maturity and reproductive period of swimming blue crab Callinectes danae Smith, 1869 (Brachyura: Portunidae) from Guaratuba Bay, Paraná State, southern Brazil. Nauplius, 21(1), 43-52.

Mura, M., Orrù, F., \& Cau, A. (2005). Size at sexual maturity of the spider crab Anamathia rissoana (Decapoda: Majoidea) from The Sardinian Sea. Journal of Crustacean Biology, 25(1), 110-115.

Ng, P. K. L., Lee, B. Y., \& Tan, H. H. (2015). Notes on the taxonomy and ecology of Labuanium politum (De Man, 1887) (Crustacea: Sesarmidae), an obligate arboreal crab on the nipah palm, Nypa fruticans (Arecales: Arecaceae). Raffles Bulletin of Zoology, 31, 216-225.

Öndes, F., Kaiser, M. J., \& Murray, L. G. (2017). Relative growth and size at onset of sexual maturity of the brown crab, Cancer pagurus in the Isle of Man, Irish Sea. Marine Biology Research, 13(2), 237-245.

Rostant, L. V., Alkins-Koo, M., \& Maitland, D. P. (2008). Growth and maturity in the Manicou Crab Eudaniela garmani (Brachyura: Pseudothelphusidae) from Trinidad, West
Indies. Journal of Crustacean Biology, 28(3), 485-493.

Rufino, M., Abelló, P., \& Yule, A. B. (2004). Male and female carapace shape differences in Liocarcinus depurator (Decapoda, Brachyura): An application of geometric morphometric analysis to crustaceans. Italian Journal of Zoology, 71(1), 79-83.

Saher, N. U., \& Qureshi, N. A. (2012). Spatial Distribution of Uca sindensis (Crustacea, Ocypodidae) along the coast of Pakistan. Egyptian Academic Journal of Biological Science, 4(1), 119-129.

Sekiguchi, K., Seshimo, H., \& Sugita, H. (1998). Post-Embryonic development of the Horseshoe Crab. The Biological Bulletin, 174(3), 337-345.

Silva, L. S., Martinelli-Lemos, J. M., Ferreira, M. A. P., \& Rocha, R. M. (2012). Gonadal development in the freshwater crab Sylviocarcinus pictus (H. Milne Edwards, 1853) (Brachyura: Trichodactylidae) from Guamá river, state of Pará, Brazil. Annals of the Brazilian Academy of Sciences, 84(3), 789-798.

Tallack, S. M. L. (2007). The reproductive cycle and size at maturity observed in Cancer pagurus in the Shetland Islands, Scotland. Journal of Marine Biological Association of the United Kingdom, 87, 1181-1189.

Zar, J. H. (1996). Biostatistical Analysis. Prentice-Hall: Upper Saddle River. 